\title{
Purification and characterization of human transcortin
}

\author{
Utz W. MUELLER and Julia M. POTTER* \\ Department of Pharmacology, University of Western A ustralia, Queen Elizabeth II Medical Centre, \\ Nedlands 6009, Western Australia, Australia
}

(Received 11 March 1981/Accepted 7 May 1981)

\begin{abstract}
Human transcortin was purified to apparent homogeneity from plasma by a two-step procedure involving affinity and hydroxyapatite chromatography. The affinity gel incorporated denatured bovine serum albumin as the spacer and cortisol hemisuccinate as the ligand. Although isolated transcortin showed a propensity for spontaneous polymerization according to a geometric progression $(1,3,9)$, only one band was observed on sodium dodecyl sulphate/polyacrylamide-gel electrophoresis. Cortisolbinding activity of the isolated protein gave an apparent association constant of $2.5 \times 10^{8} \mathrm{M}^{-1}$ at $4^{\circ} \mathrm{C}$ in equilibrium dialysis. Isoelectric focusing of purified native transcortin showed six discrete bands, five between $\mathrm{pH} 3.75$ and 4.15 and another, possibly desialylated, at $\mathrm{pH}$ 6.15. Desialylated transcortin also gave six bands on isoelectric focusing, with $\mathrm{pI}$ values ranging from 4.90 to 6.30 .
\end{abstract}

The fundamental observation that cortisol, the major plasma glucocorticoid in humans, was reversibly bound with high affinity to a corticosteroidbinding protein is attributed to Daughaday (1956). In 1962, Seal \& Doe $(1962 a, b)$ isolated a glycoprotein, which had all the then known characteristics of corticosteroid-binding globulin ('CBG') (synonymous with transcortin), by using classical techniques of protein separation. With the advent of affinity chromatography, the number of purification steps has been decreased and the yield has been increased (Rosner \& Bradlow, 1971). The present investigation describes the isolation of transcortin from plasma by affinity chromatography in which cortisol hemisuccinate was linked to Sepharose 4B by using bovine serum albumin, and an examination of some of the physicochemical parameters of the purified protein, particularly its microheterogeneity and propensity for aggregation.

\section{Materials and methods}

\section{Plasma preparation}

Plasma and serum were obtained by pooling excess remaining after biochemical diagnostic tests in local clinical-chemistry laboratories. Endogenous cortisol was removed by incubating pooled material with $5 \%(\mathrm{w} / \mathrm{v})$ charcoal at $43^{\circ} \mathrm{C}$ for $2 \mathrm{~h}$. The charcoal was removed by centrifuging twice at $10000 \mathrm{~g}$ for $10 \mathrm{~min}$. The plasma was diluted $1: 2$ with

Abbreviation used: SDS, sodium dodecyl sulphate.

* To whom correspondence and requests for reprints should be addressed.
$50 \mathrm{mM}$-sodium phosphate buffer, $\mathrm{pH} 7.0$, containing $200 \mathrm{~mm}-\mathrm{NaCl}$.

\section{Preparation of affinity gel}

Activation of Sepharose 4B beads (Pharmacia) for coupling to denatured bovine serum albumin was based on the method described by Cuatrecasas (1970). Activation of the beads was performed in the presence of $500 \mathrm{~mm}-\mathrm{Na}_{2} \mathrm{CO}_{3}$ buffer, $\mathrm{pH} 10.5$, then washed with approx. 2 litres of cold $\left(4^{\circ} \mathrm{C}\right) 100 \mathrm{mM}$ $\mathrm{NaHCO}_{3}$ buffer, pH9.0. The activated gel $(25 \mathrm{ml})$ was incubated with $200 \mathrm{mg}$ of bovine serum albumin (Sigma) in $100 \mathrm{~mm}-\mathrm{NaHCO}_{3}$ buffer, $\mathrm{pH} 9.0$, containing $10 \mathrm{M}$-urea. Coupling occurred overnight at $4^{\circ} \mathrm{C}$. The unbound protein was removed during exhaustive washing with $1 \%(\mathrm{w} / \mathrm{v}) \mathrm{NaCl}$.

Cortisol 21-hemisuccinate $(60 \mathrm{mg})$ (Steraloids, Wilton, NH, U.S.A.), being a single band on t.l.c., was coupled to the denatured albumin-Sepharose conjugate by the mixed-anhydride-condensation reaction (Erlanger et al., 1957).

\section{Transcortin extraction from plasma}

The affinity gel was normally diluted $1: 3$ with untreated Sepharose $4 \mathrm{~B}$ to minimize loss. The gel was mixed with diluted plasma at $4^{\circ} \mathrm{C}$ for $60 \mathrm{~min}$, the beads recovered by centrifugation at $2000 \mathrm{~g}$ and $4^{\circ} \mathrm{C}$ for $5 \mathrm{~min}$, the supernatant decanted and the gel transferred to a column. It was washed with $50 \mathrm{~mm}$-sodium phosphate buffer $(\mathrm{pH} 7.0) / 200 \mathrm{~mm}$ $\mathrm{NaCl}$ at $4^{\circ} \mathrm{C}$ until the column effluent showed an $A_{280}$ of less than 0.1 . After a change of buffer, to $1 \mathrm{mM}$-sodium phosphate, $\mathrm{pH} 7.0$, cortisol $(100 \mu \mathrm{g} /$ 
$\mathrm{ml}$ in $1 \mathrm{~mm}$-phosphate buffer, $\mathrm{pH} 7.0$ ) was passed through the column. When cortisol was detected emerging from the column, flow was stopped and the column re-equilibrated to $30^{\circ} \mathrm{C}$. During the subsequent $2 \mathrm{~h}$ cortisol equilibration, the gel was periodically mixed by repeated column inversions. After $2 \mathrm{~h}$ the affinity gel was eluted with 1 column vol. of fresh cortisol/phosphate buffer. The effluent was freeze-dried and stored at $-20^{\circ} \mathrm{C}$. Efficiency of transcortin extraction from plasma was determined by multiple equilibrium dialysis for $48 \mathrm{~h}$ (Table 1 below).

The chemical stability of the affinity gel was determined by determination of cortisol in plasma both before and after gel exposure. Cortisol was extracted from plasma with ethanol $(1: 4, \mathrm{v} / \mathrm{v})$ and measured by using competitive protein binding (Murphy, 1967).

\section{Hydroxyapatite chromatography}

Hydroxyapatite (Bio-Gel HTP; Bio-Rad) was equilibrated with $1 \mathrm{mM}$-sodium phosphate buffer, pH 6.8, at $4^{\circ} \mathrm{C}$. Chromatography was performed at $4^{\circ} \mathrm{C}$ in a $2.6 \mathrm{~cm} \times 15 \mathrm{~cm}$ column, with a flow rate of $0.4 \mathrm{ml} / \mathrm{min}$. Protein was eluted stepwise at $4^{\circ} \mathrm{C}$ : transcortin with equilibration buffer and other proteins with $650 \mathrm{~mm}$-potassium phosphate, $\mathrm{pH} 6.8$. The eluted transcortin was freeze-dried and stored at $-20^{\circ} \mathrm{C}$.

\section{Polyacrylamide-gel electrophoresis}

The technique of polyacrylamide-gel electrophoresis was adapted from that described by Davis (1964). Gels of either 7.2 or $10.3 \%(w / v)$ polyacrylamide were used. SDS/polyacrylamide-gel electrophoresis, was performed as described by Weber \& Osborn (1969). Proteins were stained with $0.1 \%$ Coomassie Blue R-250 in ethanol/water/acetic acid $(5: 13: 2$, by vol.) for $3 \mathrm{~h}$ and were passively destained in the same solvent.

\section{Immunoelectrophoresis}

This was performed essentially as described by Grabar \& Williams (1953). Agarose (Type 1) (Sigma) and $50 \mathrm{~mm}$-sodium barbital buffer, pH 8.6, containing $0.05 \% \mathrm{NaN}_{3}$ were used throughout Electrophoresis was performed over an extended distance of $18 \mathrm{~cm}$ at $4^{\circ} \mathrm{C}$ with $10 \mathrm{~V} / \mathrm{cm}$. Twodimensional immunoelectrophoresis (Clarke \& Freeman, 1967) was performed under similar conditions. Immunoprecipitates were allowed to develop overnight at $23^{\circ} \mathrm{C}$ in a humid chamber and then stained as described above for the polyacrylamide gels.

\section{Column chromatography}

DEAE-cellulose was obtained as the microgranular fully swollen gel (DE-52; Whatman) and prepared as recommended by the manufacturer. It was poured into a $0.9 \mathrm{~cm} \times 15 \mathrm{~cm}$ column, with a bed height of $11.5 \mathrm{~cm}$; a flow rate of $0.5 \mathrm{ml} / \mathrm{min}$ was used. Sephadex G-200 gel (Pharmacia) filtration was performed in a $2.6 \mathrm{~cm} \times 100 \mathrm{~cm}$ column with $20 \mathrm{mM}$ Tris/phosphate buffer (pH 8.0)/150 mM-NaCl/0.05\% $\mathrm{NaN}_{3}$ with downward flow.

\section{Isoelectric focusing}

Isoelectric-focusing experiments were performed in $0.9 \mathrm{~cm} \times 11 \mathrm{~cm}$ rods of polyacrylamide gel as recommended by the ampholyte manufacturer (BioRad). Preliminary experiments with ampholytes (pH 3-10) showed transcortin to have a low isoelectric point (approx. 4). Narrow-range ampholyte (pH 3-5) was added to the wide-range ampholyte in the ratio $2: 1(\mathrm{v} / \mathrm{v})$. Focusing was performed at $4^{\circ} \mathrm{C}$ for $19 \mathrm{~h}$, initially at $10 \mathrm{~V} / \mathrm{cm}$ for $1 \mathrm{~h}$, then $18 \mathrm{~h}$ at $25 \mathrm{~V} / \mathrm{cm}$. After focusing, the gel was passed longitudinally through a wire grid, giving a rectangular segment $1.1 \mathrm{~mm}$ thick by $7 \mathrm{~mm}$ wide and two segments with radii of approx. $3.9 \mathrm{~mm}$. One of the hemicylindrical segments was stained as described above under 'Immunoelectrophoresis'. The other was cut into $0.5 \mathrm{~cm}$ slices, each of which was placed in $1 \mathrm{ml}$ of distilled water and the ampholytes allowed to diffuse out overnight. The $\mathrm{pH}$ was measured separately in each portion and the gradient determined. The rectangular segment was used as the first dimension in two-dimensional immunoelectrophoresis with antiserum against human transcortin incorporated within the second-dimension agarose (type C; Pharmacia).

\section{Desialylation}

Desialylation of human transcortin was performed with Clostridium perfringens neuraminidase (Boehringer-Mannheim) in $10 \mathrm{~mm}$-sodium acetate buffer, pH 5.5 , at $37^{\circ} \mathrm{C}$ for $90 \mathrm{~min}$. For $500 \mu \mathrm{g}$ of transcortin, 0.06 enzyme unit removed all sialic acid within $30 \mathrm{~min}$ [as determined by the method of Warren (1959)]. Incubating transcortin with $50 \mathrm{mM}$ $\mathrm{H}_{2} \mathrm{SO}_{4}$ at $75^{\circ} \mathrm{C}$ for $1 \mathrm{~h}$ gave the same number of residues.

\section{Immunization}

Antiserum directed toward the isolated human transcortin preparation was raised in adult rabbits as described by Mueller \& Potter (1979).

\section{Results}

Cortisol-binding proteins extracted from plasma were monitored by multiple equilibrium dialysis (Table 1). The validity of this form of analysis is dependent on the heat-lability of human transcortin in cortisol-free plasma (Doe et al., 1964). However, the results suggest that there is another relatively 
Table 1. Multiple-equilibrium dialysis of plasma before and after treatment with affinity gel

Plasma (2 litres) was treated with $20 \mathrm{ml}$ of cortisol-affinity gel at $4^{\circ} \mathrm{C}$. Cortisol-binding activity before and after treatment was measured with all samples being dialysed concurrently for $48 \mathrm{~h}$ at $4{ }^{\circ} \mathrm{C}$ with $350 \mu \mathrm{g}$ unlabelled and $250 \mathrm{pg}$ of $\left[1,2,6,7(\mathrm{n}){ }^{-3} \mathrm{H}\right]$ cortisol in $120 \mathrm{ml}$ of $50 \mathrm{~mm}$-sodium phosphate buffer, $\mathrm{pH} 7.4$. Plasma was diluted 1:6. The cortisol bound to 'transcortin' was calculated by difference from before and after treatment at $60^{\circ} \mathrm{C}$ for $30 \mathrm{~min}$. The first and second extractions indicate successive plasma incubations with the same affinity gel.

Native plasma

Plasma after first extraction (1)

Plasma after second extraction (2)

(1) Heated at $60^{\circ} \mathrm{C}$

(2) Heated at $60^{\circ} \mathrm{C}$

Native plasma heated
${ }^{3} \mathrm{H}$ radioactivity

$\begin{array}{cccc}\begin{array}{c}\text { Inside sac } \\ \text { (c.p.m./0.5 ml) }\end{array} & \begin{array}{c}\text { Outside sac } \\ \text { (c.p.m./0.5 ml) }\end{array} & \begin{array}{c}\text { Total bound } \\ \text { (c.p.m./0.5 ml) }\end{array} & \begin{array}{c}\text { 'Transcortin' } \\ \text { bound } \\ \text { (c.p.m./0.5 ml) }\end{array} \\ 10980 & 2240 & 8740 & 7110 \\ 10430 & 2240 & 8190 & 7230 \\ 9810 & 2240 & 7570 & 6660 \\ 3150 & 2240 & 960 & - \\ 3200 & 2240 & 910 & - \\ 3870 & 2240 & 1630 & -\end{array}$

Table 2. Qualitative assessment of protein species in affinity-column effluent by separation on Sephadex G-200: Ouchterlony (1948) double diffusion against various monospecific antisera

All anti-(hiuman immunoglobulins) antisera were obtained from Kallestad Laboratories, Chaska, MN, U.S.A. The notation,+++++ and + refers to the intensity of precipitation. Abbreviation used: IgM, immunoglobulin $M$ etc.

Intensity of precipitation

\begin{tabular}{|c|c|c|c|c|c|}
\hline & \multicolumn{5}{|c|}{ Intensity of precipitation } \\
\hline Molecular-weight rạnge & $\ldots>270000$ & $\begin{array}{c}\text { II } \\
270000- \\
170000\end{array}$ & $\begin{array}{c}\text { III } \\
170000- \\
140000\end{array}$ & $\begin{array}{c}\text { IV } \\
140000- \\
58000\end{array}$ & $\begin{array}{c}V \\
58000- \\
38000\end{array}$ \\
\hline
\end{tabular}

Anti-IgM ( $\mu$-chain)

Anti-IgA ( $(a-c h a i n)$

Ariti-IgG ( $\gamma$-chain)

Ánti-transcơtin

Anti-albumin

Anti-IgD ( $\delta$-chain)

Anti-IgE ( $\varepsilon$-chain)

heat-insensitive cortisol-binding protein in plasma apart from albumin, and that transcortin extraction from plasma cannot be confidently assessed by considering only residual cortisol binding. For this reason, transcortin extraction was measured retrospectively by radial immunodiffusion (Mancini et al., 1965). In the first extraction, $11 \mathrm{mg}$ of transcortin was recovered, representing $63 \%$ of that bound to the gel, and in the second, $14 \mathrm{mg}(61 \%)$. As the extraction procedures were performed on consecutive days with the same $20 \mathrm{ml}$ of affinity gel, it appears that the gel is stable to repeated plasma exposures in the short term.

After freeze-drying of the product from the column, its purity with respect to transcortin was examined by analytical polyacrylamide-gel, electrophoresis (Fig. 1, gel A). Gel B (Fig. 1) is the pooled effluent resulting from re-incubation in cortisol/ buffer of the previously eluted gel. Two bands are common to $\mathrm{A}$ and $\mathrm{B}$, including a band that migrated only a short distance into the gel. Fig. 2 shows immunoelectrophoresis at $\mathrm{pH} 8.6$ of whole plasma compared with the affinity-column effluent after passage through DEAE-cellulose. Proteins were detected by using anti-(human whole plasma) antiserum. The proteins eluted from the DEAEcellulose column show low electrophoretic mobility, which was highly suggestive of immunoglobulins being the major contaminating protein species derived from the affinity gel. That more than one species of immunoglobulin was present, since immunoglobulin $\mathrm{G}$ isolated from the affinity-column product by a passage through DEAE-cellulose could not account for the entire $\gamma$-globulin species (Fig. 2), was confirmed by using specific rabbit antisera. The affinity-column effluent was fractionated according to its molecular weight on a calibrated Sephadex G-200 column. The effluent was pooled into five fractions, defined as in Table 2. The volume of each fraction was decreased to $3 \mathrm{ml}$ in an Amicon model-52 ultrafiltration unit with a Diaflow PM10 membrane under nitrogen pressure. Double- 


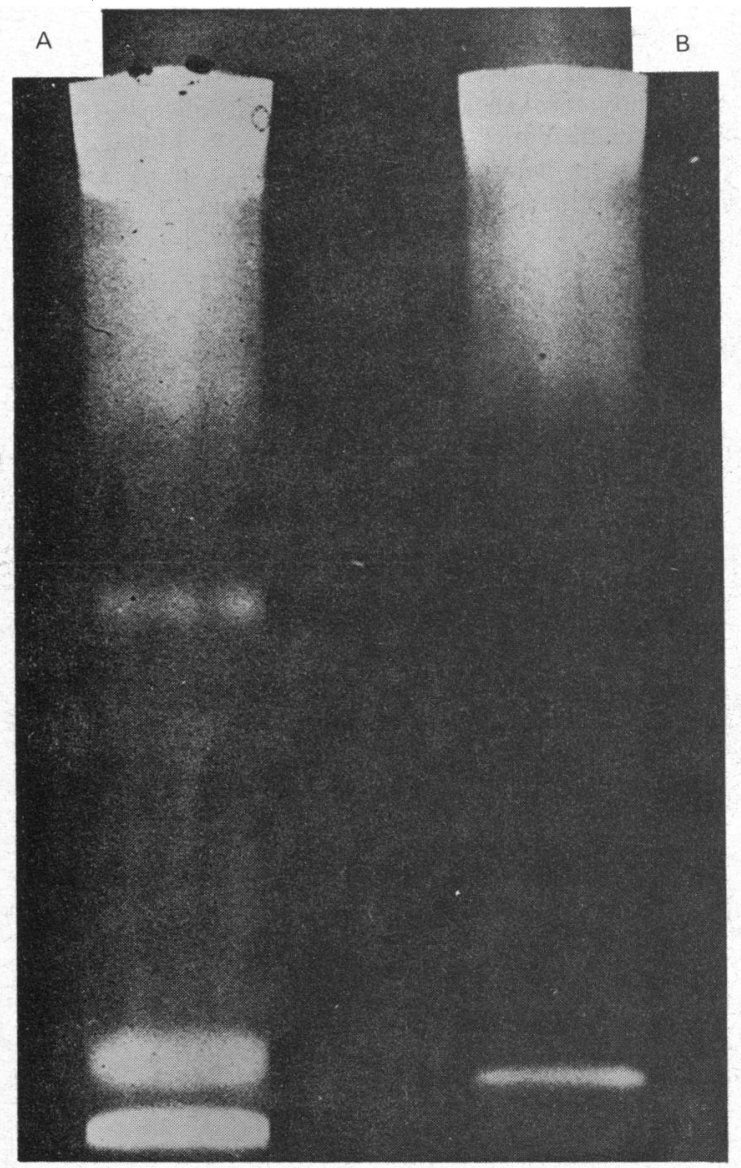

Fig. 1. Polyacrylamide-gel electrophoresis of pooled affinity-column eluate

Gel A shows polyacrylamide-gel electrophoresis of pooled cortisol-affinity-column eluate resulting from a single exposure of $2 \mathrm{~h}$ to cortisol $(100 \mu \mathrm{g} / \mathrm{ml})$ in $1 \mathrm{~mm}$-sodium phosphate buffer, $\mathrm{pH}$ 7.0. Gel $\mathrm{B}$ is polyacrylamide-gel electrophoresis after the affinity gel was reincubated for a futher $2 \mathrm{~h}$ with a bed volume of cortisol in the same buffer. Electrophoresis was from top to bottom of the gels. Proteins were stained with Coomassie Blue R-250 and are shown as a negative photograph.

immunodiffusion (Ouchterlony, 1948) analysis of the proteins is shown in Table 2. This confirmed the presence of immunoglobulins $\mathbf{G}$ and $A$ and allowed their separation from the bulk of the transcortin.

Further purification of the affinity-gel product with hydroxyapatite

Since the affinity-column product was not homogeneous with respect to transcortin, a further purification step was required. Since immuno-

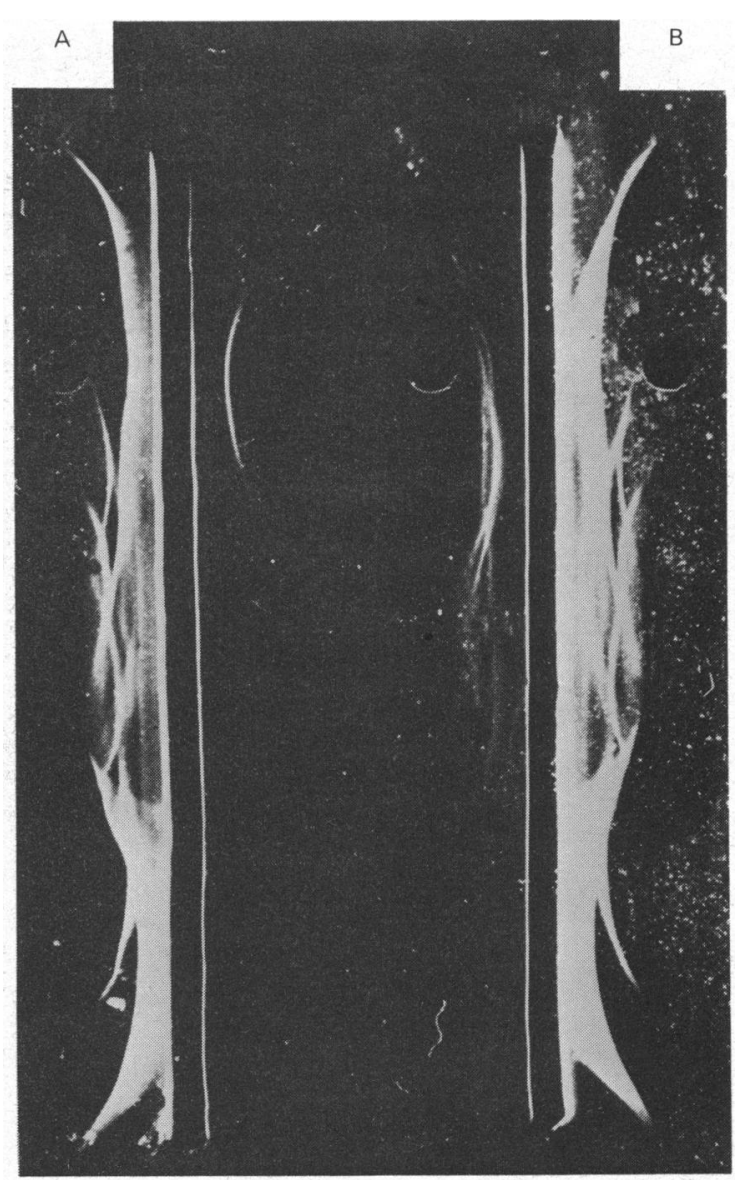

Fig. 2. Zonal electrophoresis of DEAE-cellulosefractionated cortisol-affinity-gel eluate

Zonal electrophoresis was performed on agarose (relative mobility -0.14 ), with $50 \mathrm{~mm}$-sodium barbital buffer, $\mathrm{pH} 8.6$, at $4^{\circ} \mathrm{C}$. Protein migration was from the circular well down toward the bottom of the photograph. On the left-hand side of trough A, whole plasma was electrophoresed, with affinitycolumn protein, which passed unretarded through DEAE-cellulose gel ( $\mathrm{pH} 8.0$ ), running on the right of A. To the right of trough B, whole plasma is shown compared with retarded DEAE-cellulose-gel protein on the left. After electrophoresis, rabbit anti-(human plasma) antiserum was placed in troughs $A$ and $B$. Protein precipitates were allowed to develop for $48 \mathrm{~h}$, the plate being placed in a humid chamber at $23^{\circ} \mathrm{C}$.

globulins were present in the affinity product with potentially high binding affinity for cortisol, a second passage through a second affinity column would be unlikely substantially to change the composition. In 1962, Seal \& Doe $(1962 a, b)$ demonstrated that partially purified transcortin could be completely 
isolated by repeated passages through hydroxyapatite gel. Transcortin in the post-affinity-column material was found to elute with 1 mM-sodium phosphate buffer, pH6.8, from hyroxyapatite, with unbound cortisol coming after the void volume.
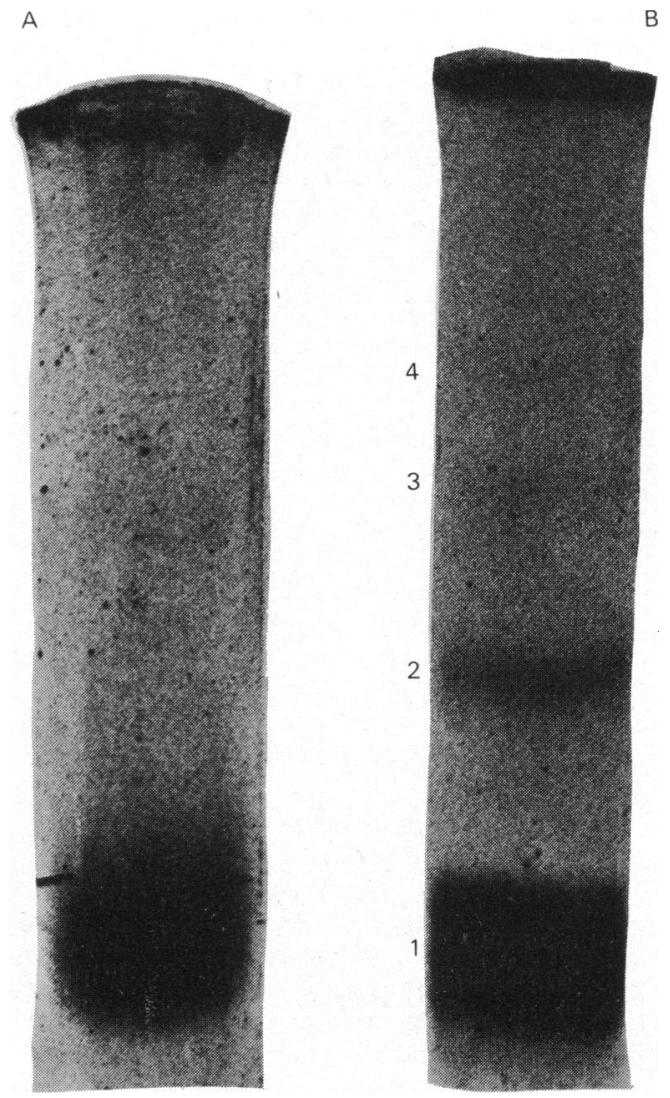

Fig. 3. Polyacrylamide-gel electrophoresis of hydroxyapatite-eluted transcortin

A, SDS/polyacrylamide-gel electrophoresis of transcortin is shown. Transcortin from the affinity-gel product was eluted unretarded through hydroxyapatite with $1 \mathrm{~mm}$-sodium phosphate, pH6.8. Approx. $200 \mu \mathrm{g}$ of protein was loaded on to the $10.3 \%$-polyacrylamide gel, and electrophoresis was performed in a continuous buffer system. Protein migration was from top to bottom of the gel. Only one discrete band stained with Coomassie Blue R-250. B, In this instance a discontinuous buffer system described by Davis (1964) was utilized. Transcortin, eluted unretarded through hydroxyapatite, was loaded on to $10.3 \%$ polyacrylamide, and electrophoresis performed for $60 \mathrm{~min}$ at $3 \mathrm{~mA}$ / tube. Protein migration was from top to bottom of the gel. The poorly staining protein was made visible with Coomassie Blue R-250 after overnight staining followed by passive destaining. Multiple entities indicated by $1,2,3$, etc. are readily observed.
Elution was performed in the presence of a large molar excess of cortisol, to minimize spontaneous aggregation of transcortin (Le Gaillard et al., 1975). Elution with $1 \mathrm{mM}$-phosphate is in accord with observations of Seal \& Doe $(1962 a)$, but in contrast with those of Schneider \& Slaunwhite (1971) and Le Gaillard et al. (1974), who required 20 and $5 \mathrm{~mm}$-phusphate respectively to effect transcortin elution from the column. The method of hydroxyapatite production may account for these differences (Le Gaillard et al., 1974).

After the eluate from hydroxyapatite had been freeze-dried, examination by polyacrylamide-gel electrophoresis (Fig. 3, gel B) revealed more than one protein band. Either the preparation was not homogeneous with respect to transcortin, or the transcortin itself was present in multiple forms. Evidence for an homogeneous protein comes from two independent methods. Injection of the singlepassage post-hydroxyapatite material into rabbits resulted in a monospecific antiserum, as shown by immunoelectrophoresis and crossed immunoelectrophoresis of whole human plasma (Fig. 4). Immunization will show the presence of any contaminant species by antibody production to all antigenic entities. Electrophoresis of plasma in agarose over the extended migratory distance shows transcortin to migrate with an $R_{\text {albumin }}$ of 0.69 , i.e. as an inter- $\alpha$-globulin, a result consistent with that obtained by Rosner \& Bradlow (1971).

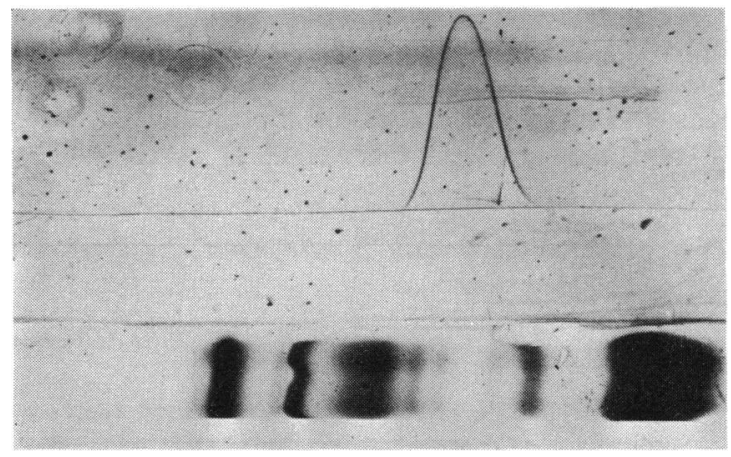

Fig. 4. Two-dimensional immunoelectrophoresis of whole human plasma by using antiserum raised against isolated transcortin

Zonal electrophoresis in the first dimension was conducted in agarose over an extended albumin migration distance of $18 \mathrm{~cm}$. The plasma proteins were then electrophoresed at right angles into agarose incorporating transcortin antibodies. The observed single precipitin curve is indicative of antibodies raised against an homogeneous antigen, namely transcortin. 
The pattern of relative migration on polyacrylamide-gel electrophoresis (Fig. 3, gel B) is consistent with a polymerized protein. Marinis \& Ott (1964) demonstrated that polymerized proteins appear to migrate in polyacrylamide gels according to their net charge and spherical volume, allowing relative migration to be predicted with reasonable accuracy. Table 3 shows the predicted mobility for some protein associations, and compares them with the experimental results obtained with transcortin. The observed mobility for transcortin polymers appears to proceed according to a geometric progression $1,3,9$, etc. This pattern is distinct from that shown by albumin, which occurs in the series 1 , 2, 4, 8, etc. (Marinis \& Ott, 1964). The observed mobilities of transcortin polymers are calculated by assuming that the species with the greatest mobility is monomer. Pretreatment of the polymerized material with protein-dissociating agents, SDS and $\beta$-mercaptoethanol before electrophoresis results in a single species (Fig. 3, gel A). The observation suggests that transcortin readily forms polymers and does not have non-identical protein subunits of significantly different molecular weight within the native monomeric conformation.

\section{Equilibrium dialysis of transcortin}

Biological activity of isolated transcortin was ascertained by cortisol binding in equilibrium dialysis at $4^{\circ} \mathrm{C}$. As it seemed that isolated transcortin had a propensity to polymerize even in the presence of excess cortisol, as shown on the polyacrylamide gels, the freeze-dried transcortin, saturated with an approx. 8-fold molar excess of cortisol, was dissolved in $50 \mathrm{~mm}$-sodium phosphate buffer, pH 7.4, containing 1 mM-disodium EDTA and 2 mM- $\beta$-mercaptoethanol. The protein concentration was $4.45 \mu \mathrm{g} / \mathrm{ml}$ (determined by subtracting the water of crystallization and the weight of cortisol). The

Table 3. A comparison of observed and expected mobilities for transcortin polymers

$\begin{array}{ccc}\begin{array}{c}\text { Monometric } \\ \text { units in } \\ \text { polymer }\end{array} & \overbrace{\text { Expected }}^{\text {Mobility (relative to monomer) }} \\ 1 & 1 & \text { Observed }(n=4) \\ 2 & 0.794 & 1 \\ 3 & 0.693 & 0.675 \pm 0.01 \\ 4 & 0.630 & \\ 5 & 0.585 & \\ 6 & 0.550 & \\ 8 & 0.500 & \\ 9 & 0.481 & 0.480 \pm 0.005 \\ 16 & 0.396 & 0.360 \pm 0.005 \\ 27 & 0.333 & 0.225 \pm 0.005 \\ 81 & 0.231 & \end{array}$

water of crystallization, measured by drying to constant weight, was $14.1 \%$. The cortisol concentration was determined by competitive protein binding (Murphy, 1967). No attempt was made to remove any associated cortisol from the protein, and dialysis was performed against increasing volumes of external buffer. The resulting data are presented as a Scatchard (1949) plot (Fig. 5). By the method of unweighted least squares, an association constant of $2.5 \times 10^{8} \mathrm{M}^{-1}$ with 0.97 binding sites was calculated. A molecular weight of 51700 for transcortin was used (Muldoon \& Westphal, 1967).

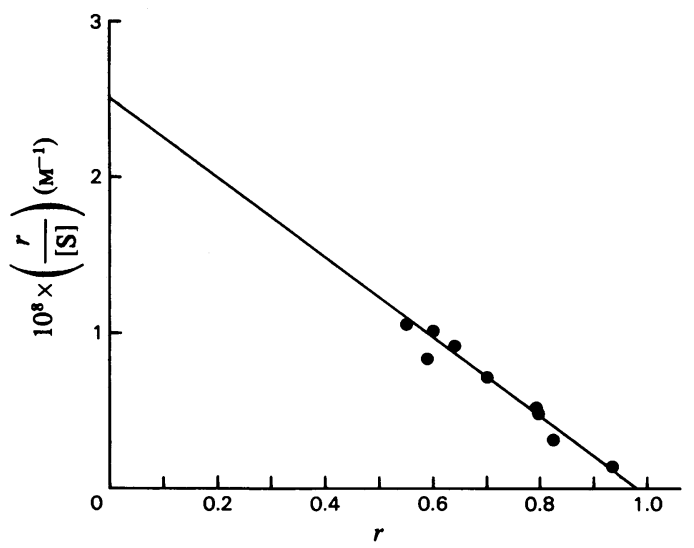

Fig. 5. Equilibrium dialysis of isolated transcortin against cortisol: data transformation by Scatchard (1949) plot Equilibrium dialysis of isolated transcortin against cortisol was performed at $4^{\circ} \mathrm{C}$. Cortisol-saturated transcortin was dialysed against increasing volumes $(25-250 \mathrm{ml})$ of $50 \mathrm{~mm}$-sodium phosphate buffer, pH7.4, containing a trace of $\left[{ }^{3} \mathrm{H}\right]$ cortisol. Use of cortisol-saturated material was to minimize transcortin denaturation before dialysis. The resultant binding data was transformed into a Scatchard (1949) plot, where $r$ is the amount of cortisol bound ( $\mathrm{mol} / \mathrm{mol}$ of protein) and $[\mathrm{S}]$ is the molar concentration of unbound steroid. An association constant of $2.5 \times 10^{8} \mathrm{M}^{-1}$ and one binding site per molecule of transcortin was found.

Table 4. Isoelectric focusing of native and desialylated transcortin derived from normal plasma

Results are means \pm S.E.M. (n). Protein was desialylated using neuraminidase.

$\begin{array}{cccc}\text { Band } & \text { Transcortin } & \overbrace{\ldots \text { Native }}^{\text {Desialylated }} \\ 1 & \mathrm{pI} \\ 2 & 3.75 \pm 0.05(4) & 4.90 \pm 0.05(2) \\ 3 & 3.95 \pm 0.05(4) & 5.10 \pm 0.05(2) \\ 4 & 4.05 \pm 0.05(4) & 5.45 \pm 0.05(2) \\ 5 & 4.15 \pm 0.05(4) & 5.80 \pm 0.05(2) \\ 6 & 6.15 \pm 0.05(4) & 6.30 \pm 0.05(2) \\ & & & \end{array}$




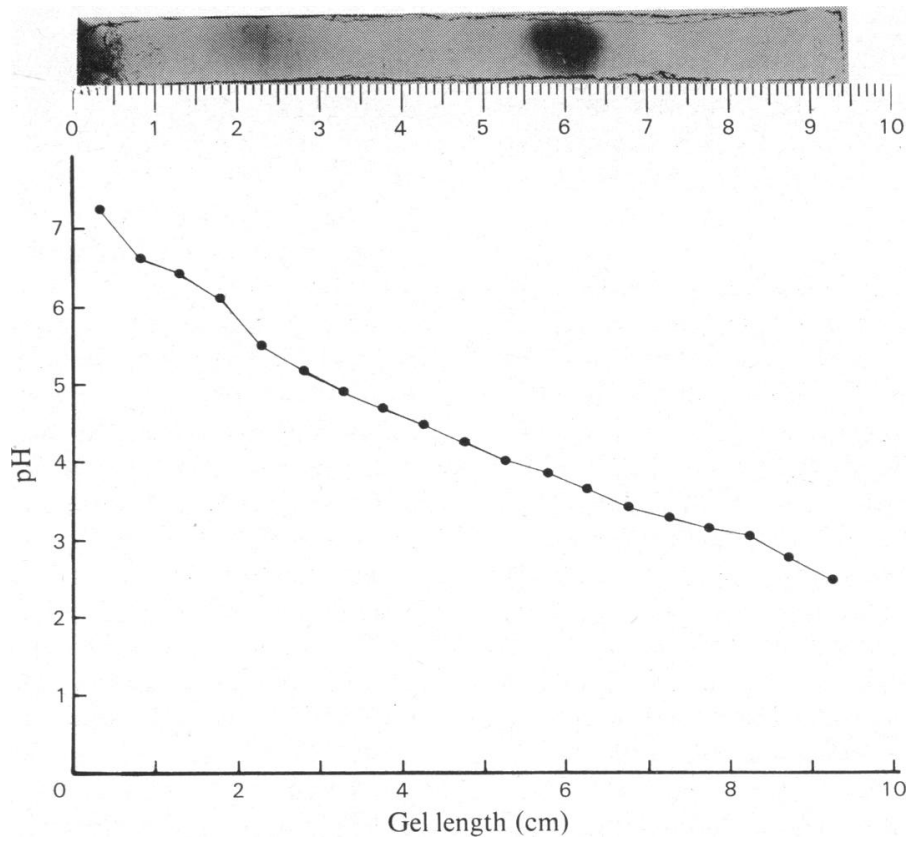

Fig. 6. Isoelectric focusing of human plasma transcortin

Isoelectric focusing was performed on polyacrylamide rods $(0.9 \mathrm{~cm} \times 11 \mathrm{~cm})$ at $4^{\circ} \mathrm{C}$. Focusing was done initially at $10 \mathrm{~V} / \mathrm{cm}$ for $1 \mathrm{~h}$, followed by $18 \mathrm{~h}$ at $25 \mathrm{~V} / \mathrm{cm}$. The gel containing the focused protein was cut longitudinally. One segment stained with Coomassie Blue R-250 is shown. The other segment was used to determine the pH gradient, which is shown below.

\section{Sialic acid content}

By using mild-acid or enzymic hydrolysis, $6.4 \%$ by weight (or 10.8 residues of sialic acid/molecule). of transcortin was found.

\section{Isoelectric focusing}

Fig. 6 shows the polyacrylamide hemicylindrical segment containing stained focused native transcortin. Table 4 shows the corresponding pI values for each of the six bands observed in both native and desialylated transcortin.

\section{Discussion}

Human transcortin from plasma was successfully isolated to apparent homogeneity by a two-step purification using affinity chromatography and passage through hydroxyapatite. The protein, although apparently homogeneous in terms of its electrophoretic migration at $\mathrm{pH} 8.6$ and its antigenic capacity, showed on further investigation many of the characteristics of other plasma glycoproteins. Isoelectric focusing revealed the presence of six species. The protein showed a marked tendency to spontaneous polymerization, as shown on polyacrylamide-gel electrophoresis, pretreatment with SDS resulting in only one band. Biological activity of the material was demonstrated by its ability to bind cortisol with an apparent $K_{\mathrm{a}}$ of $2.5 \times 10^{8} \mathrm{M}^{-1}$ at $4^{\circ} \mathrm{C}$ and one binding site/molecule of protein.

Unlike other methods, the affinity chromatography in the present study utilized cortisol hemisuccinate linked by denatured bovine serum albumin to the agarose matrix. Use of bovine serum albumin offered many advantages, particularly multiple sites for steroid coupling and linkage on to agarose. Although the length of the spacer is important in determining retention of the binding compound (Cuatrecasas, 1972), the need to establish an optimal length becomes unnecessary, since the complex protein structure will provide a range of spacer lengths. Use of bovine serum albumin also offered possible steric hindrance of plasma esterases and protected the ester linkage between cortisol and albumin. The use of cortisol hemisuccinate as ligand has been criticized on the grounds of its susceptibility to plasma esterases (Le Gaillard et al., 1974). However, two successive exposures of affinity gel to plasma resulted in loss of neither cortisol from the gel nor binding ability of the gel. Chemical esterolysis at a pH higher than 8.0 (Garrett, 1962) was never encountered under the elution conditions used. The protein recovered from the affinity gel consisted of transcortin itself, a small quantity of albumin, and a significant amount of immunoglobulins, both $A$ and $G$. This is consistent with a 
very low extent of non-specific association. As discussed below, it would seem that the immunoglobulins have a high affinity for cortisol, as judged by their resistance to elution from the column.

\section{Immunoglobulins}

The presence of immunoglobulins $A$ and $G$ in the affinity-gel product is consistent with the findings of both Rosner \& Bradlow (1971) and Le Gaillard et al. (1974). As observed by those authors, on their isolation these immunoglobulins did not display significant cortisol-binding activity. As the immunoglobulins have an apparently high affinity for the gel, as judged by the amount present, the apparent lack of cortisol-binding activity may be related to the isolation conditions. The existence of immunoglobulins with cortisol-binding activity deserves further investigation. Although it is possible to elicit antibody response to steroids bound covalently to protein (Erlanger et al., 1957), doubt exists as to whether steroids binding reversibly to protein could give a similar response. When haptenization of steroids is undertaken for the purpose of antibody production, the exposed portion of the steroid extending out from the carrier protein determines the specificity of the antibodies (Midgley \& Niswender, 1970). Examination of the affinity-gel chemistry indicates that the A-ring of cortisol is exposed. If then the immunoglobulin binding is directed towards the A-ring of the cortisol moiety, it is unlikely that transcortin-bound cortisol serves for antigenic stimulation of anti-cortisol antibodies. Electron-spinresonance studies indicate that the lateral chain at position-17 of transcortin-bound cortisol is orientated outwards (Basset et al., 1975). This moiety is significantly altered by the hemisuccinate group on the affinity gel and would also be sterically hindered by its proximity to the agarose matrix.

\section{Microheterogeneity}

Purified transcortin displayed many of the characteristics common to plasma glycoproteins, in which polydispersion or microheterogeneity is the rule rather than the exception (Gibbons, 1972). Immunization of rabbits with apparently homogeneous transcortin resulted in an antiserum that was able to detect a single protein peak when tested against either injected antigen or whole human plasma. SDS-treated material also gave rise to a single band on polyacrylamide-gel electrophoresis. This latter observation suggests only that if more than one constituent is present, there are no major differences in either molecular weight or net charge under these conditions. However, on isoelectric focusing, several clearly defined bands were present. An equal number of bands were seen in the desialylated material, and it is likely that the bands shown in the desialylated material represent differences due to amino acid composition and/or carbohydrate other than sialic acid. These differences may be responsible for some of the variability seen in the published amino acid analyses, with different proportions of the species present in individual preparations (Seal \& Doe, 1962a; Muldoon \& Westphal, 1967; Schneider \& Slaunwhite, 1971).

Normal native transcortin focuses around $\mathrm{pH} 4$, as postulated by Van Baelen \& De Moor in 1972. Bernutz et al. (1979) indicated that transcortin focused as five bands between $\mathrm{pH} 3.7$ and 4.2. Their $\mathrm{pH}$ gradient failed to encompass possible desialylated species. Rosner [quoted in Van Baelen \& De Moor (1972)] obtained a single band with pI of 3.94, which corresponds to the mean of the five bands around $\mathrm{pH} 4$ shown in the present study.

The minor transcortin species that focuses at pI6.15 in the native and desialylated preparation probably represents desialylated protein. It is unlikely to be due to acidic desialylation during preparation or focusing. As at least 11 residues of sialic acid per molecule reside terminally on transcortin's carbohydrate moiety, it might be expected that successive cleavage of these residues might occur when the molecule is exposed to an acidic environment. Such sequential loss should yield a number of partially desialylated transcortin species along the length of the $\mathrm{pH}$ gradient. On these grounds this desialylated species is most likely native in the plasma. Desialylated transcortin has been shown to maintain its full cortisol-binding activity and compete with native transcortin for binding sites on a cortisol affinity gel (Muldoon \& Westphal, 1967). The approximate proportion of this minor desialylated species to normal transcortin is $1-2 \%$, as judged by the density of staining and by the areas under precipitin curves in the two-dimensionalimmunoelectrophoresis studies. It is unlikely that under normal electrophoresis this slower-migrating species would be detected in whole plasma with conventional protein-identification techniques.

The six bands seen on desialylation differ in number and $\mathrm{pI}$ from those observed by Van Baelen \& De Moor (1972). However, they utilized whole plasma and their identification was based on cortisol-binding activity only. Bernutz et al. (1979) contended that desialylation of native transcortin produces one major and minor band. However, a pH range of 3.5-10 was used to focus the desialylated material, and this may not be sufficient to allow detection of separate species.

\section{Polymerization}

Spontaneous polymerization of human transcortin has been previously reported (Rosner, 1972; Le Gaillard et al., 1975; Werthamer et al., 1973). Earlier workers using protein purified by classical chromatography were not able to demonstrate the 
phenomenon (Seal \& Doe, 1962b; Muldoon \& Westphal, 1967; Schneider \& Slaunwhite, 1971). Migration of transcortin polymers on polyacrylamide-gel electrophoresis in the present study suggested a geometric association of monomeric units, $1,3,9$, etc. It has previously been assumed that the first transcortin polymer is dimer (Rosner, 1972) and thiol linkage has been implicated (Le Gaillard $e t$ al., 1975). However, there is evidence that polymerization may be reversed by using SDS and urea, as in the present paper and elsewhere (Werthamer $e t$ al., 1973; Basset et al., 1977). It may be that transcortin polymerization is of two types, one time-dependent, as in the present study, being reversible early in its course, and the second such as produced by heat treatment (U. W. Mueller \& J. M. Potter, unpublished work). Ultracentrifugal data provide support for such a possibility (Le Gaillard et al., 1975). Transcortin also undergoes polymerization in plasma, as demonstrated immunochemically by Werthamer et al. (1973) and more recently by ourselves (U. W. Mueller \& J. M. Potter, unpublished work).

In view of the apparent spontaneous polymerization of purified native transcortin, interpretation of binding data from equilibrium dialysis must be cautious. Since inactivation of binding activity of human transcortin occurs on complete stripping of endogenous cortisol at $45^{\circ} \mathrm{C}$ by gel filtration (Muldoon \& Westphal, 1967), isolated transcortin was stored in the presence of a large molar cortisol excess. Likewise, affinity and bindingsite determinations with transcortin were performed at cortisol concentrations close to saturation. Low protein concentrations were used to maximize the possibility of determining the cortisol association constant and number of binding sites for transcortin monomer. The value of $2.5 \times 10^{8} \mathrm{M}^{-1}$ at $4^{\circ} \mathrm{C}$ is in accord with other published results $\left[6.3 \times 10^{8} \mathrm{M}^{-1}\right.$ (Seal and Doe, 1962a); $5.2 \times 10^{8} \mathrm{M}^{-1}$ (Muldoon \& Westphal, 1967); $1.5 \times 10^{8} \mathrm{M}^{-1}$ (Le Gaillard et al., 1975)], as is the binding site. It should be noted that these values were obtained when the protein was in very dilute concentration. However, since transcortin at physiological concentrations in plasma self-associates or polymerizes with a concomitant loss of binding sites and/or affinity, these values are physiologically uncertain (Mueller \& Potter, 1981).

\section{References}

Basset, M., Defaye, G. \& Chambaz, E. M. (1975) FEBS Lett. 60, 364-368
Basset, M., Defaye, G. \& Chambaz, E. M. (1977) Biochem. Biophys. Res. Commun. 79, 380-387

Bernutz, C., Hansle, W. O., Horn, K., Pickardt, C. R., Scriba, P. C., Fink, E., Kolb, H. \& Tschesche, H. (1979) Acta Endocrinol. (Copenhagen) 92, 370-384

Clarke, H. G. M. \& Freeman, T. A. (1967) Protides Biol. Fluids Proc. Colloq. 14, 503-509

Cuatrecasas, P. (1970) J. Biol. Chem. 245, 3059-3065.

Cuatrecasas, P. (1972) Adv. Enzymol. Relat. Areas Mol. Biol. 36, 29-89

Daughaday, W. H. (1956) J. Clin. Invest. 35, 1428-1433

Davis, B. J. (1964) Ann. N.Y. Acad. Sci. 121, 404-427

Doe, R. P., Fernandez, R. \& Seal, U. S. (1964) J. Clin. Endocrinol. Metab. 24, 1029-1039

Erlanger, B. F., Borek, F., Beiser, S. M. \& Lieberman, S. (1957) J. Biol. Chem. 228, 713-727

Garrett, E. R. (1962) J. Med. Pharm. Chem. 8, 112-116

Gibbons, R. A. (1972) in Glycoproteins: Their Composition and Function (Gottschalk, A., ed.), pp. 31-127, Elsevier Publishing Co., Amsterdam

Grabar, P. \& Williams, C. A. (1953) Biochem. Biophys. Acta 10, 193-194

Le Gaillard, F., Racadot, A., Racadot-Leroy, N. \& Dautrevaux, M. (1974) Biochimie 56, 99-108

Le Gaillard, F., Han, K. \& Dautrevaux, M. (1975) Biochimie 57, 559-568

Mancini, G., Carbonara, A. O. \& Heremans, J. F. (1965) Immunochemistry 2, 235-254

Marinis, S. \& Ott, H. (1964) Protides Biol. Fluids Proc. Colloq. 11, 420-422.

Midgley, A. R. \& Niswender, G. D. (1970) Acta Endocrinol. (Copenhagen) Suppl. 147, 320-327

Mueller, U. W. \& Potter, J. M. (1979) Anal. Biochem. $100,51-53$

Mueller, U. W. \& Potter, J. M. (1981) Biochem. Pharmacol. 30, 727-733

Muldoon, T. G. \& Westphal, U. (1967) J. Biol. Chem. 242, 5636-5643

Murphy, B. E. P. (1967) J. Clin. Endocrinol. Metab. 27, 973-990

Ouchterlony, O. (1948) Acta Pathol. Microbiol. Scand. 25, 186-191

Rosner, W. (1972) J. Steroid Biochem. 3, 531-542

Rosner, W. \& Bradlow, H. L. (1971) J. Clin. Endocrinol. Metab. 33, 193-198

Scatchard, G. (1949) Ann. N.Y. Acad. Sci. 51, 660-672

Schneider, S. L. \& Slaunwhite, W. R., Jr. (1971) Biochemistry 10, 2086-2093

Seal, U. S. \& Doe, R. P. (1962a) Cancer Chemother. Rep. $16,329-334$

Seal, U. S. \& Doe, R. P. (1962b) J. Biol. Chem. 237, 3136-3140

Van Baelen, H. \& De Moor, P. (1972) J. Steroid Biochem. 3, 321-323

Warren, L. (1959) J. Biol. Chem. 234, 1971-1975

Weber, K. \& Osborn, M. (1969) J. Biol. Chem. 244, 4406-4412

Werthamer, S., Samuels, A. J. \& Amaral, L. (1973) J. Biol. Chem. 248, 6398-6407 